\title{
The use of negative pressure wound therapy in the treatment of wound infections - a single-center 12-month experience
}

\author{
Krzysztof Kępa, Łukasz Krzych, Tomasz Wacławczyk, Michał Krejca \\ Oddział Kardiochirurgii, Górnośląskie Centrum Medyczne w Katowicach
}

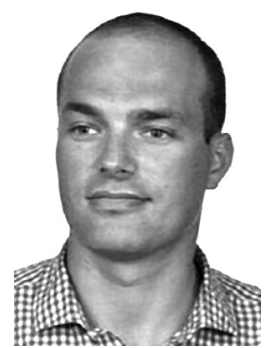

Kardiochirurgia i Torakochirurgia Polska 2013; 10 (3): 204-210

\begin{abstract}
Background: The prevalence of surgical site infections (SSI) in cardiac surgery is about $0.5-10 \%$, according to different sources, and leads to a prolonged hospital stay and higher mortality. The aim of the study was to describe the clinical outcomes of our 12-month experience using negative pressure wound therapy (NPWT).

Material and methods: We performed a retrospective analysis of 32 patients undergoing NPWT between October 1, 2011 and September 30, 2012 (i.e. 2.7\% of all patients who underwent surgical treatment in this period). Patient characteristics, risk factors, and procedure-related variables were analyzed and compared in two groups: group 1 included patients with infection of skin and subcutaneous tissue (1.2\%), while group 2 consisted of patients with mediastinitis (1.6\%).

Results: Mediastinitis was three times more frequent among women ( $p=0.09)$ and diabetics ( $p=0.08)$, and four times more frequent in patients with chronic obstructive pulmonary disease $(p=0.2)$. The most frequently performed procedure was coronary artery bypass grafting (87.5\%). Methicillin-resistant Staphylococcus epidermidis (26.2\%) and Pseudomonas aeruginosa (21\%) were the pathogens that were most frequently isolated from the infected wounds. The mean time of hospitalization was $64 \pm 35$ days, which was similar in the two studied groups. In-hospital mortality in the mediastinitis group was 16.7\%; no deaths were related to the use of NPWT therapy.

Results: Our findings indicate that NPWT is a viable option for SSI treatment. Moreover, the use of NPWT may lower patient mortality, as well as reduce the length and costs of hospitalization. In order to achieve this, however, it is necessary to diagnose the infection early and to implement adequate treatment.
\end{abstract}

Key words: cardiac surgery, infection, treatment, NPWT, VAC.

\section{Streszczenie}

Wstęp: Częstość występowania infekcji rany chirurgicznej (ang. surgical site infections - SSI) po operacjach kardiochirurgicznych wynosi według różnych źródeł od 0,5\% do 10\%, co prowadzi do wydłużenia pobytu pacjentów w szpitalu oraz zwiększenia śmiertelności w okresie pooperacyjnym.

Celem badania było przedstawienie 12-miesięcznych doświadczeń własnych dotyczących leczenia infekcji rany po sternotomii z użyciem terapii podciśnieniowej (ang. negative pressure wound therapy - NPWT).

Materiat i metody: Retrospektywnej analizie poddano 32 pacjentów z zastosowaną NPWT, których leczono od 1 października 2011 r. do 30 września 2012 r. (stanowili oni 2,7\% wszystkich operowanych chorych w tym okresie). Porównano przebieg i wyniki leczenia dwóch grup pacjentów: $z$ infekcją rany obejmującą skórę i tkankę podskórną (I grupa, $n=1,2 \%$ ) oraz z zapaleniem śródpiersia (II grupa, $n=1,5 \%$ ).

Wyniki: Zapalenie śródpiersia ponad 3-krotnie częściej występowało u kobiet $(p=0,09)$ oraz osób z cukrzycą $(p=0,08)$, a 4-krotnie częściej u osób z obturacyjną chorobą płuc $(p=0,2)$. Zdecydowana większość ocenianych pacjentów $(87,5 \%)$ miała wykonane pomostowanie naczyń wieńcowych. Najczęstszymi wyizolowanymi patogenami były: metycylino-oporny gronkowiec skórny (26,2\%) oraz pałeczka ropy błękitnej (21\%). Średni czas łącznej hospitalizacji wynosił $64 \pm 35$ dni i był zbliżony w obu grupach. Trzy osoby z zapaleniem śródpiersia zmarły podczas hospitalizacji (śmiertelność $=16,7 \%$ ).

Wnioski: Wstępne doświadczenia zachęcają do wdrażania NPWT do leczenia chorych z SSI. Wśród chorych leczonych przy użyciu NPWT możliwa wydaje się redukcja czasu i kosztów hospitalizacji oraz zmniejszenie liczby powikłań zakażenia, jednak tylko pod warunkiem wczesnego jego rozpoznania i wdrożenia odpowiedniego leczenia.

Słowa kluczowe: kardiochirurgia, zakażenie, leczenie, terapia podciśnieniowa, VAC. 


\section{Introduction}

The prevalence of surgical site infection (SSI) after cardiac surgery is $0.5-10 \%$, according to different sources [1-3]. This complication most often occurs in wounds after sternotomy (the most commonly chosen access in cardiac surgery), as well as in the sites from which material for coronary artery bypass grafting was harvested (this concerns both venous bypasses and arterial bypasses other than those using the internal thoracic artery) $[3,4]$.

Despite the use of broad-spectrum antibiotic prophylaxis, rigorous adherence to antiseptic and aseptic guidelines, significant improvement of the quality of surgical techniques, and shorter duration of cardiac surgery procedures, sternotomy wound infections are still common postoperative complications, the prevalence of which ranges from $1 \%$ to $5 \%$ for all types of cardiac surgery. The most severe form of sternotomy wound infection is mediastinitis, which occurs in $1-3 \%$ of all cardiac patients. This condition greatly increases the postoperative mortality rate - even up to $10-25 \%$ [1-4].

Traditionally, SSI risk factors are categorized into patientdependent and surgeon/procedure dependent. The first group includes: diabetes, excessive body mass, smoking tobacco, renal insufficiency, osteoporosis, steroid use, female gender, decreased left ventricular function, reoperation, chronic obstructive pulmonary disease, malnutrition, immunosuppression, emergency surgery, and the necessity of perioperative transfusion. The second group consists of the following factors: the use of extracorporeal circulation (especially prolonged aortic cross-clamping), hypothermia, inadequate control of body temperature and glucose level, hemodilution and low hemoglobin level, perfusion disorders and hypotension, hyperglycemia, prolonged ICU stay and total hospital stay, mechanical ventilation, the use of both internal thoracic arteries, delayed chest closure, reopening of the chest, and decreased vigilance with regard to aseptic measures [5-8].

The signs of SSI include: purulent exudate, increased wound/body temperature, pain and sensitivity of the wound, instability of the sternum, reddening and swelling, tissue damage, and unpleasant smell coming from the wound [5-7].

\section{Aim of the study}

The aim of this study is to present our 12-month experience with treating sternotomy wound infections by means of negative pressure wound therapy (NPWT).

\section{Material and methods}

The study included patients operated on at the First Cardiac Surgery Ward of the Upper Silesian Medical Center in Katowice between October 1, 2011 and September 30, 2012. Among the 1180 patients who underwent surgery within the mentioned period, 32 (2.7\%) required the use of NPWT because of median sternotomy wound infection. None of the patients required NPWT due to wound infections in sites other than sternal wounds.
All patients were treated by 4-person teams composed of nurses and doctors, in accordance with the uniform, standard guidelines employed at the Ward. After diagnosing the infection and qualifying the patient for treatment supported by negative pressure therapy, the preparation and dressing of the wound for NPWT for the first time was always performed in an operating room with the assistance of an anesthesiologist. The performed tasks included: taking smears from both poles of the wound, disinfecting the skin around the wound, thoroughly cleaning the wound of necrotic and infected tissue, as well as applying lavage and aseptic measures. In the case of sternal instability, the metal elements stabilizing the anterior chest wall were removed. Afterwards, negative pressure dressing (vacuum-assisted closure - VAC) was applied to the wound, in compliance with the guidelines of the manufacturer.

The VAC dressing was changed every $48-72 \mathrm{~h}$ in a treatment room setting, providing the patient with adequate analgesia or analgosedation. The procedures described in detail above were performed in aseptic conditions (smears, cleaning, lavage, wound asepsis, and the application of new dressings). In VAC therapy, dressings covered in nanocrystalline silver (Acticoat flex ${ }^{\circledR}$ ) were used under black polyurethane foam (GranuFoam ${ }^{\circledR}$ ). White foam hydrophilic dressings (Vers-Foam ${ }^{\mathrm{TM}}$ ) made of polyvinyl alcohol (PVA) were not used in any of the cases. We used a negative pressure of $125 \mathrm{~mm} \mathrm{Hg}$ (initially in all patients), which is preferred in VAC dressings. In 5 patients, the negative pressure value had to be reduced to $75-100 \mathrm{~mm} \mathrm{Hg}$ because of severe pain present despite the optimization of analgesia.

Targeted antibiotic therapy was used during the NPWT treatment, based on the current bacteriological results of wound cultures, along with constant blood sugar level monitoring (optimal $<140 \mathrm{mg} / \mathrm{dL}$ ) and the monitoring of complete blood count, inflammatory marker levels, and creatinine values.

The successful healing of the infection was established on the basis of negative culture test results and macroscopic evaluation of the wound. Restabilization of the sternum (if the metal connections had been previously removed) and chest wall reconstruction were performed in operating room conditions. Collagen sponge saturated with highly concentrated garamycin (Garamycin ${ }^{R}$ ) was applied under the connected parts of the sternum. Depending on the level of sternal instability, metal sutures, clamps (Sternal Zip$\mathrm{Fix}^{\mathrm{R}}$ ), and, in certain cases, bone cement (Kryptonite ${ }^{\mathrm{R}}$ ) were used. Subcutaneous tissue and skin were stitched with single sutures (monofilaments). Moreover, a Redon type drain was implanted on the anterior part of the sternum along the entire wound for 3-5 days, or until the drained secretions decreased significantly.

Apart from the complete healing of the infection, bleeding of the sternotomy wound or the presence of skin lesions resulting from significant irritation by the dressing foil constituted indications for the discontinuation of the NPWT therapy. 
For the purpose of analysis, the patients were divided into two groups. The first group included 14 patients $(1.2 \%)$, in whom the bones of the sternum were not infected (skin and subcutaneous tissue infection). The second group consisted of 18 patients (1.5\%) with diagnosed mediastinitis.

Statistical analysis was conducted on the basis of the procedures available in the licensed MedCalc software. Quantitative variables were presented as arithmetic mean and standard deviation, while qualitative variables were presented as absolute values and/or percentages. Differences between the groups for quantitative variables were verified on the basis of the results of the Mann-Whitney $U$ test or Student's $t$-test. In the case of qualitative variables, the $\chi^{2}$ test was used. The nature of quantitative variable distribution was verified by means of the Kolmogorov-Smirnov test. Appropriate odds ratios and their 95\% confidence intervals were evaluated using qualitative variable relation assessment. Statistical significance of $p<0.05$ was assumed.

\section{Results}

The study encompassed 19 women and 13 men at the mean age of $65 \pm 8$. A detailed description of the patients, including their division into groups, is presented in Table I. It was found that mediastinitis occurred 3.5 times more often in women than in men, 3.6 times more often in patients with diabetes, and 4.4 times more often in patients with obstructive pulmonary disease. These observations, however, were not statistically significant.

The vast majority of patients, 28 (87.5\%), underwent coronary artery bypass grafting (group 1: 13 patients, group 2: 15 patients). 16 patients (50\%) had 2 bypasses implanted, while 6 patients (18.75\%) received 3 bypasses. All patients underwent arterial revascularization (LITA: 28 patients, BITA: 1 patient from group 2). The bypass was performed without the use of extracorporeal circulation in only 2 patients from group $2(\mathrm{OR}=4.63 ; 95 \% \mathrm{Cl}$ : 0.2-106; $p=0.3)$. Moreover, valve surgery was performed in $4 \mathrm{pa}-$ tients: aortic valve replacement (2 patients) with tricuspid annuloplasty (1 patient), mitral valve replacement (2 patients) with tricuspid annuloplasty (1 patient). Complex procedures were performed in 3 cases (bypass with mitral valve replacement, bypass with mitral annuloplasty, bypass with mitral valve replacement and tricuspid annuloplasty). No statistically significant differences between the groups were found with regard to any of the parameters related to the conducted procedure $(p>0.05)$. Emergency procedures were performed in 9 cases (group 1: 5 patients, group 2: 4 patients; $\mathrm{OR}=1.94 ; 95 \% \mathrm{Cl}: 0.4-9.2 ; p=0.6)$.

The mean durations of aortic cross-clamping, extracorporeal circulation, and the procedure are presented in Table II. There were no statistically significant differences between the groups established on the basis of the extent

Tab. I. Patient characteristics

\begin{tabular}{|c|c|c|c|c|c|}
\hline Variable & $\begin{array}{c}\text { Total } \\
N=32\end{array}$ & $\begin{array}{l}\text { Group } 1 \\
N=14\end{array}$ & $\begin{array}{c}\text { Group } 2 \\
N=18\end{array}$ & OR $(95 \% \mathrm{Cl})$ & $P$ \\
\hline Female gender & $19(59.4 \%)$ & $6(42.9 \%)$ & $13(72.2 \%)$ & $3.47(0.8-15.2)$ & 0.09 \\
\hline Age [years] & $65 \pm 8$ & $66 \pm 6$ & $64 \pm 9$ & - & 0.6 \\
\hline Body mass [kg] & $79.8 \pm 13.1$ & $77.9 \pm 10.8$ & $81.4 \pm 14.9$ & - & 0.5 \\
\hline Height $[\mathrm{cm}]$ & $164.7 \pm 8.4$ & $165.9 \pm 7.2$ & $163.6 \pm 9.4$ & - & 0.5 \\
\hline $\mathrm{BMI}\left[\mathrm{kg} / \mathrm{m}^{2}\right]$ & $29.3 \pm 4.6$ & $28.3 \pm 3.9$ & $30.2 \pm 5.1$ & - & 0.3 \\
\hline Obesity (BMI $\geq 30)$ & $14(45.2 \%)$ & $7(50 \%)$ & $7(41.2 \%)$ & $0.7(0.2-2.91)$ & 0.8 \\
\hline Atrial fibrillation & $9(28.1 \%)$ & $3(21.4 \%)$ & $6(33.3 \%)$ & $1.83(0.4-9.17)$ & 0.7 \\
\hline Diabetes & $17(53.1 \%)$ & $5(35.7 \%)$ & $12(66.7 \%)$ & $3.6(0.83-15.6)$ & 0.08 \\
\hline Condition after $\mathrm{PCl}$ & $10(31.2 \%)$ & $4(28.6 \%)$ & $6(33.3 \%)$ & $1.25(0.27-5.7)$ & 0.8 \\
\hline Obstructive pulmonary disease & $2(6.25 \%)$ & 0 & $2(11.1 \%)$ & $4.0(0.19-99.2)$ & 0.2 \\
\hline Chronic kidney disease & $3(9.4 \%)$ & $1(7.2 \%)$ & $2(11.1 \%)$ & $1.53(0.1-18.8)$ & 0.7 \\
\hline Peripheral atherosclerosis & $4(12.5 \%)$ & $2(14.4 \%)$ & $2(11.1 \%)$ & $0.75(0.1-6.11)$ & 0.8 \\
\hline Left ventricular ejection fraction & $46 \pm 8$ & $43 \pm 8$ & $48 \pm 8$ & - & 0.2 \\
\hline EuroScore II [\%] & $2.29 \pm 1.74$ & $2.09 \pm 1.61$ & $2.54 \pm 1.93$ & - & 0.5 \\
\hline
\end{tabular}

$\mathrm{Cl}$ - confidence interval, $\mathrm{OR}$ - odds ratio, $\mathrm{PCl}$ - percutaneous coronary intervention

Tab. II. Operative parameters

\begin{tabular}{lccc} 
Variable & Total & Group 1 & Group 2 \\
Aortic cross-clamping duration [min] & $51.4 \pm 31.8$ & $53.0 \pm 40.0$ & $50.0 \pm 23.8$ \\
\hline Extracorporeal circulation duration [min] & $80.6 \pm 49.1$ & $82.0 \pm 60.3$ & $79.3 \pm 40.0$ \\
\hline Procedure duration [min] & $215.4 \pm 65.1$ & $215.6 \pm 40.0$ & $215.2 \pm 68.1$ \\
\hline
\end{tabular}


Tab. III. Sternal wound culture test results during therapy

\begin{tabular}{|c|c|c|c|c|}
\hline Pathogen & $\begin{array}{c}\text { Total } \\
N=256\end{array}$ & $\begin{array}{l}\text { Group } 1 \\
N=106\end{array}$ & $\begin{array}{l}\text { Group } 2 \\
N=150\end{array}$ & $P$ \\
\hline Staphylococcus epidermidis MRSE & $67(26.2 \%)$ & $25(23.6 \%)$ & $42(28 \%)$ & 0.5 \\
\hline Pseudomonas aeruginosa & $54(21 \%)$ & $22(20.7 \%)$ & $32(21.3 \%)$ & 0.9 \\
\hline Escherichia coli & $23(8.7 \%)$ & $11(10.4 \%)$ & $12(8 \%)$ & 0.7 \\
\hline Enterococcus faecalis & $21(8.2 \%)$ & $8(7.6 \%)$ & $13(8.7 \%)$ & 0.9 \\
\hline Klebsiella pneumoniae & $17(6.8 \%)$ & $5(4.8 \%)$ & $12(8 \%)$ & 0.4 \\
\hline Staphylococcus epidermidis MSSE & $7(2.7 \%)$ & $2(1.8 \%)$ & $5(3.3 \%)$ & 0.7 \\
\hline Staphylococcus aureus MSSA & $6(2.3 \%)$ & $4(3.8 \%)$ & $2(1.3 \%)$ & 0.4 \\
\hline Staphylococcus aureus MRSA & $2(0.8 \%)$ & $1(0.9 \%)$ & $1(0.7 \%)$ & 0.6 \\
\hline Negative culture tests & $59(23.3 \%)$ & $28(26.4 \%)$ & $31(20.7 \%)$ & 0.3 \\
\hline
\end{tabular}

MR - methicillin-resistant, MS - methicillin-sensitive

of infection. The mean duration of postoperative ward stay during the hospitalization related to the cardiac procedure was $7.5 \pm 14.4$ days (group 1: $4.0 \pm 3.6$ days, group 2: $10.8 \pm 19.4$ days; $p=0.5$ ). The most common undesired postoperative events were dyspnea (15 patients; group 1: 6 patients, group 2: 9 patients; $\mathrm{OR}=1.33$; $95 \% \mathrm{Cl}$ : 0.3-5.4; $p=0.9$ ) and atrial fibrillation (12 patients; group 1: 5 patients, group 2: 7 patients; $\mathrm{OR}=1.14 ; 95 \% \mathrm{Cl}: 0.3-4.9$; $p=0.8)$. Reopening of the chest was necessary in 5 cases (group 1: 3 patients, group 2: 2 patients; $p=0.7$ ).

In order to employ NPWT, 16 patients (50\%) were readmitted $46 \pm 53$ days after being discharged following their original cardiac procedure. The first hospitalization lasted $40 \pm 36$ days in total, the second (16 patients) $31 \pm 19$ days, the third (necessary in 5 cases) $68 \pm 54$ days. The mean time of the entire hospitalization was $64 \pm 35$ days and was similar in group 1 ( $61 \pm 36$ days) and group 2 ( $66 \pm 35$ days), $p=0.6$ (Fig. 1). The assignment to either of the groups did not have any statistically significant influence on the necessity of rehospitalization $(\mathrm{OR}=1.9 ; 95 \% \mathrm{Cl}$ : 0.4-8.0; $p=0.4$.

A

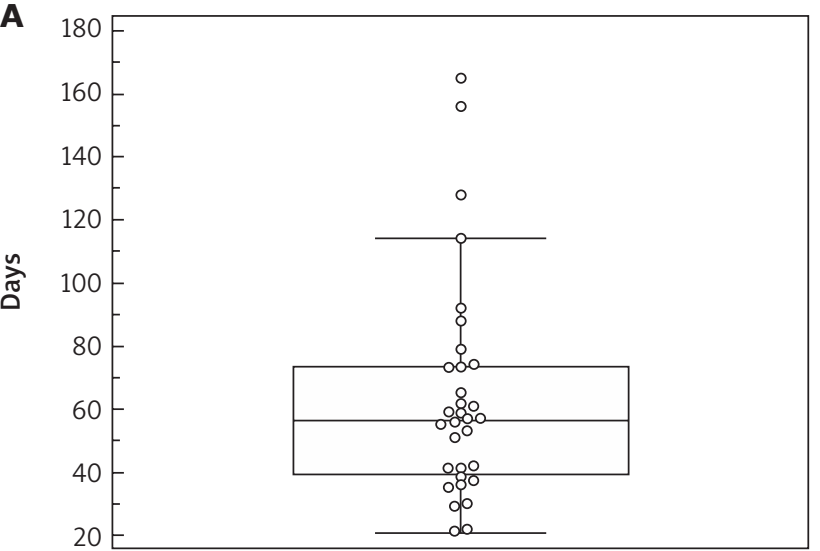

All
The duration of NPWT was $21 \pm 9$ days in total; the negative pressure therapy was approximately 7 days longer in group 2 than in group 1 and lasted $24 \pm 10$ days and $17 \pm 6$ days ( $p=0.03$ ), respectively (Fig. 2$)$. VAC dressings were applied on average $30 \pm 38$ days after the procedure (group 1: $18.6 \pm 13.2$ days, group 2: $38.1 \pm 47$ days; $p=0.06$ ). During the therapy, $7 \pm 4 \mathrm{VAC}$ sponges were used on average (group 1: $6 \pm 3$; group 2: $8 \pm 4 ; p=0.09$ ). Among all the patients, therapy with the use of a hyperbaric chamber was employed in 2 patients from the mediastinitis group and 1 patient from group $1(p=0.8)$. Garamycin sponges were used in 10 patients during the cardiac procedure (group 1: 5 patients, group 2: 5 patients; $p=0.9$ ) and in 25 patients (group 1: 11 patients, group 2: 14 patients; $p=0.7$ ) during the final suturing of the healed wound. Through drainage was applied in 3 cases (from group 2 only; OR $=6.6$; $95 \%$ $\mathrm{Cl}: 0.3-138 ; p=0.3)$.

On average, 8 culture tests were performed on a single patient during NPWT, regardless of the group. The compilation of all culture test results $(n=256)$ is presented in Table II. The most commonly isolated pathogens were: methicillin-re-

B

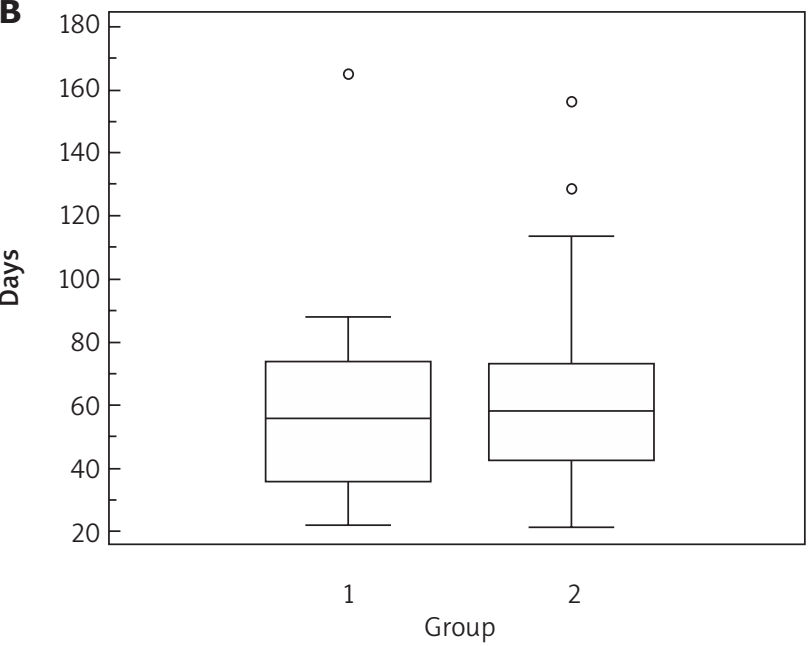

Fig. 1. Mean hospitalization time 
A

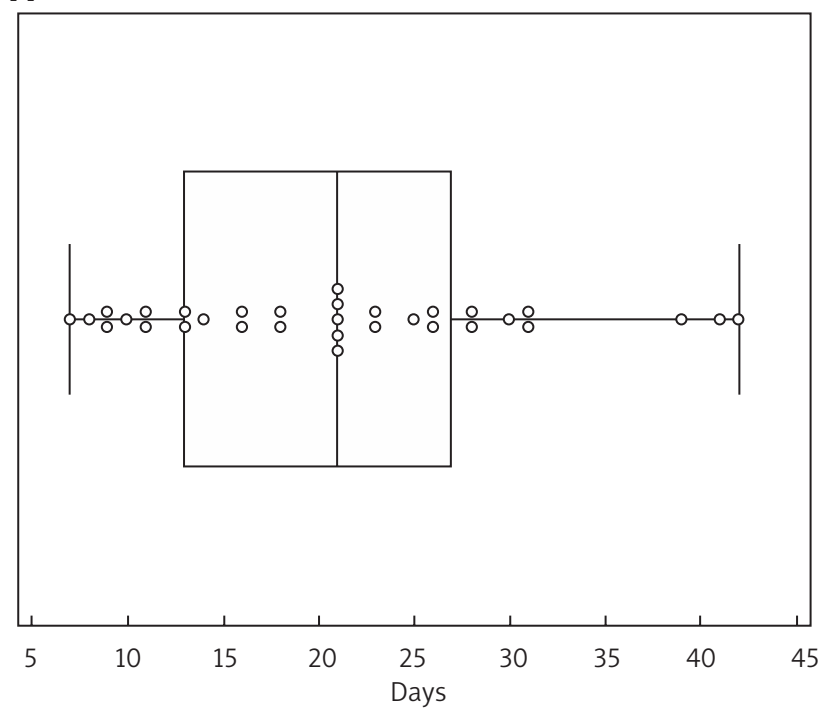

Fig. 2. NPWT duration

sistant Staphylococcus epidermidis (26.2\%) and Pseudomonas aeruginosa (21\%).

Apart from the implementation of the first antibiotic, which was empirical in nature, all patients received targeted antibiotic therapy. If it was necessary, modification took place after antibiograms had been received. The duration of treatment with the first antibiotic during NPWT was $12 \pm 4$ days and was similar in group 1 (12 \pm 4 days) and group 2 (12 \pm 4 days) ( $p=0.9)$. Fifteen patients required their medicine to be changed; the adjusted therapy lasted $13 \pm 3$ days on average (group 1: $14.5 \pm 3$ days, group 2: $12 \pm 4$ days; $p=0.2$ ). Nine patients from this group required the implementation of a third antibiotic - the adjusted therapy lasted $13 \pm 4$ days (group 1: $14 \pm 2$ days, group 2: $13 \pm 5$ days; $p=0.6$ ). Only 2 patients required the sequential inclusion of a $4^{\text {th }}$ antibiotic, which continued for $11.5 \pm 2$ days (group 1: 13 days, group 2: 10 days).

Concurrent saphenectomy wound infection occurred in 2 patients (from group 2 only; OR $=4.4 ; 95 \%$ $\mathrm{Cl}$ : 0.2-99; $p=0.4$ ). Pleurocentesis aimed at fluid evacuation was performed in 10 patients (group 1: 4 patients, group 2: 6 patients; $O R=1.25 ; 95 \% \mathrm{Cl}$ : 0.3-5.6; $p=0.8$ ); $2300 \pm 4750 \mathrm{ml}$ of fluid was drained (group 1: $550 \pm 475 \mathrm{ml}$, group 2: $4100 \pm 6700 \mathrm{ml} ; p=0.3$ ). Packed red blood cell transfusion was necessary in 22 patients in total (68.75\%) (group 1: 11 patients, group 2: 11 patients; $\mathrm{OR}=0.42 ; 95 \% \mathrm{Cl}: 0.1-2.1 ; p=0.3) ; 17$ patients from this group only required the transfusion immediately after the surgery, whereas 5 patients required it during the NPWT treatment. Four patients died during hospitalization (mortality rate in the SSI group: 12.5\%); 3 of them suffered from mediastinitis (mortality rate in the mediastinitis group: $16.7 \%$ ).

We observed no significant side effects resulting from the use of NPWT. Only 2 patients ( 1 from each group) experienced hypersensitivity to the dressing used in VAC.

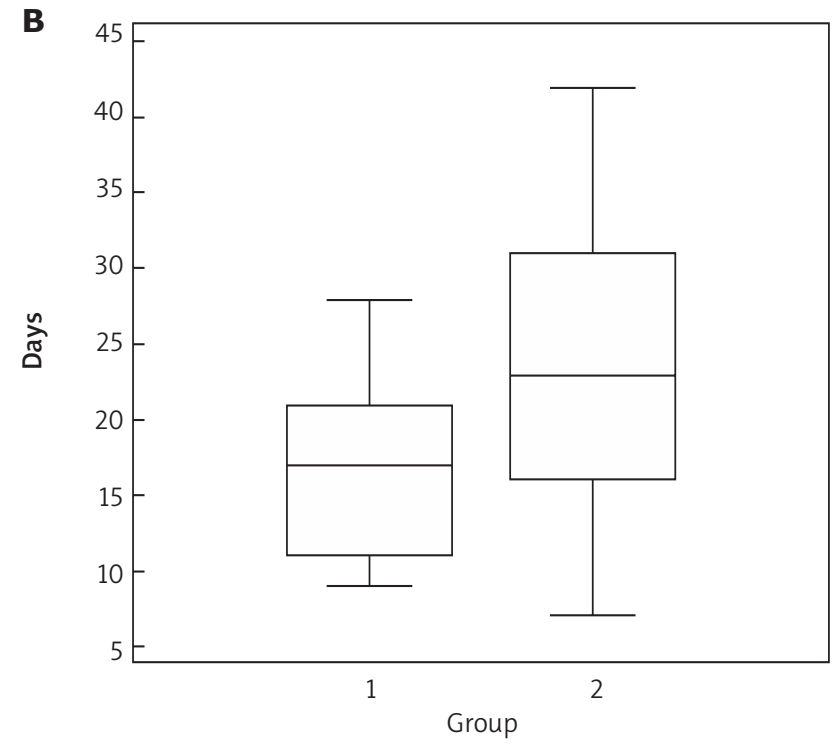

\section{Discussion}

The aim of this work was to describe our single-center experience with the treatment of superficial and deep sternal wound infections, including mediastinitis, using negative pressure therapy.

Our observations provide preliminary, but still encouraging indications that NPWT is a safe and effective method of treatment for patients with mediastinitis and patients with skin or subcutaneous tissue infections, providing similar results in both of these patient groups.

It is important to emphasize that there are no uniform guidelines in place dedicated to the use of NPWT in the treatment of sternotomy wound infections. In turn, VAC therapy is widely used in many cardiac surgery centers and constitutes an integral part of the SSI treatment protocol.

The prevalence of sternotomy wound infections and mediastinitis that we observed was comparable to the results presented in a systematic review published 5 years ago [1], as well as in other works describing this issue [7, 8].

In the presented material, mediastinitis was 3 times more frequent among women $(p=0.09)$ and patients with diabetes $(p=0.08)$ and 4 times more frequent among patients with obstructive pulmonary disease $(p=0.2)$, as confirmed by the literature [5-8]. The therapy obviously lasted longer in this group $(p=0.03)$ and the usage of resources necessary for VAC was slightly higher as well ( $p=0.09)$. It is also important to mention that the lack of statistically significant differences between the analyzed groups in terms of the remaining studied variables, especially those describing the effects of NPWT, may result from the low number of patients in the groups and their clinical heterogeneity.

Patients undergoing coronary artery bypass grafting constituted the most numerous group treated with VAC therapy. This is a typical observation, considering the fact that, with regard to the discussed profile of patients under- 
going surgery, CABG is the primary procedure. It is also important to remember that internal thoracic artery harvesting results in a local decrease in blood supply to the tissues of the sternal area (especially if both arteries are harvested), which is conducive to infection, especially in patients with diabetes. Vos et al. [9] presented similar results concerning both the above and the average duration of aortic cross-clamping, extracorporeal circulation, and surgery.

It needs to be emphasized that, in patients with more extensive infection, VAC was applied 20 days later, on average, than in patients with superficial infection. This resulted from the fact that these patients reported for check-up too late and with extensive infection; therefore, adequate treatment, such as NPWT, could not have been used sufficiently early. This underlines the importance of patient cooperation for the effectiveness of therapy. Moreover, diligent outpatient health monitoring and assessment of the wound healing process during the postoperative period are also indispensable, particularly between the $16^{\text {th }}$ and $17^{\text {th }}$ day after the cardiac procedure, when infections are most often diagnosed [10].

The most commonly isolated pathogen often differs from center to center. In the presented work, the most common diagnosis was infection caused by methicillinresistant Staphylococcus epidermidis or Pseudomonas aeruginosa, without any statistically significant differences between the previously described groups.

NPWT constitutes non-pharmacological support for the conventional therapy employed for surgical site infections, wound dehiscence, and mediastinitis. The main advantages of NPWT include: creating the negative pressure necessary for efficient wound drainage, increasing blood supply within the area of VAC dressing, accelerating wound tissue granulation, isolating the wound from the external environment, decreasing local swelling, and stabilizing the patient's respiratory tract in the case of sternal instability. The procedure employed at our ward required all the hospitalized patients to have their dressings changed in aseptic conditions by a small group of qualified doctors assisted by nurses, in accordance with the established methodology. The unification of the method helps achieve better effectiveness of its use in the daily treatment of patients and enables the inclusion of NPWT in the so-called standard protocol.

Four patients died during hospitalization, 3 of whom suffered from mediastinitis, which makes this result comparable to other reports $[7,9]$. It is important to mention that these deaths were not directly related to the infection or the employed VAC therapy.

It should be remembered that negative pressure therapy carries the risk of fatal bleeding caused by rupture of the right ventricular wall [11]. This undesired event, which would normally result in discontinuation of the therapy or have a negative impact on the patient's health, did not take place in our study.

Patients with diagnosed mediastinitis still pose a much greater challenge for cardiologists than patients with more superficial SSIs because of the a priori unfavorable prognosis, comorbidity, hindered physical and cardiopulmonary rehabilitation, and the risk of other undesired events.

The discussed therapeutic process is difficult to plan and involves significant costs, resulting not only from the use of resources for NPWT, but also from prolonged hospital stay, which accounts for over $50 \%$ of the total cost of SSI treatment and is three times more expensive than a CABG procedure [12]. This therapy is not reimbursable from the Polish National Health Service; therefore, it needs to be quick and efficient in order to minimize the incurred expenses.

The amount of literature data concerning sternotomy wound infections and the treatment of mediastinitis is limited; there are no controlled, randomized studies, which would surely provide a great deal of interesting data. It would, however, be a challenge to perform such studies because of the difficulties related to the randomization of such a heterogeneous group of patients. Nonetheless, even retrospective registry studies alone have proven that VAC therapy provides better therapeutic results than conservative SSI treatment $[1,7,8,13,14]$.

\section{Conclusions}

Initial experiences suggest that NPWT is a viable option for SSI treatment, regardless of the extent of infection.

The use of VAC therapy may allow for the reduction of the cost and duration of hospitalization and limit the number of complications resulting from infection. In order to achieve this, it is necessary to diagnose the infection early and to implement adequate treatment, usually in the form of the so-called unified standard protocol.

\section{References}

1. Raja SG, Berg GA. Should vacuum-assisted closure therapy be routinely used for management of deep sternal wound infection after cardiac surgery? Interact Cardiovasc Thorac Surg 2007; 6: 523-527.

2. Gummert JF, Barten MJ, Hans C, Kluge M, Doll N, Walther T, Hentschel B, Schmitt DV, Mohr FW, Diegeler A. Mediastinitis and cardiac surgery - an updated risk factor analysis in 10,373 consecutive patients. J Thorac Cardiovasc Surg 2002; 50: 87-91.

3. Sjögren J, Malmsjö M, Gustafsson R, Ingemansson R. Poststernotomy mediastinitis: a review of conventional surgical treatments, vacuum-assisted closure therapy and presentation of the Lund University Hospital mediastinitis algorithm. Eur J Cardiothorac Surg 2006; 30: 898-905.

4. Eklund AM, Lyytikäinen O, Klemets P, Huotari K, Anttila VJ, Werkkala KA Valtonen M. Mediastinitis after more than 10,000 cardiac surgical procedures. Ann Thorac Surg 2006; 82: 1784-1789.

5. Tadros MA, Williams VR, Plourde S, Callery S, Simor AE, Vearncombe M. Risk factors for Staphylococcus aureus surgical site infection during an outbreak in patients undergoing cardiovascular surgery. Am J Infect Control 2013; 41: 509-512.

6. Darouiche R, Mosier M, Voigt J. Antibiotics and antiseptics to prevent infection in cardiac rhythm management device implantation surgery. Pacing Clin Electrophysiol 2012; 35: 1348-1360.

7. Faraday N, Rock P, Lin EE, Perl TM, Carroll K, Stierer T, Robarts P, McFillin A, Ross T, Shah AS, Riley LH, Tamargo RJ, Black JH, Blasco-Colmenares E, Guallar E. Past history of skin infection and risk of surgical site infection after elective surgery. Ann Surg 2013; 257: 150-154.

8. Berríos-Torres SI, Mu Y, Edwards JR, Horan TC, Fridkin SK. Improved risk adjustment in public reporting: coronary artery bypass graft surgical site infections. Infect Control Hosp Epidemiol 2012; 33: 463-469. 
9. Vos RJ, Yilmaz A, Sonker U, Kelder JC, Kloppenburg GT. Primary closure using Redon drains vs vacuum-assisted closure in post-sternotomy mediastinitis. Eur J Cardiothorac Surg 2012; 42: e53-e57.

10. Berg TC, Kjørstad KE, Akselsen PE, Seim BE, Løwer HL, Stenvik MN, Sorknes NK, Eriksen HM. National surveillance of surgical site infections after coronary artery bypass grafting in Norway: incidence and risk factors. Eur J Cardiothorac Surg 2011; 40: 1291-1297.

11. Abu-Omar Y, Naik MJ, Catarino PA, Ratnatunga C. Right ventricular rupture during use of high-pressure suction drainage in the management of poststernotomy mediastinitis. Ann Thorac Surg 2003; 76: 973-979.
12. Mokhtari A, Sjögren J, Nilsson J, Gustafsson R, Malmsjö M, Ingemansson R. The cost of vacuum-assisted closure therapy in treatment of deep sternal wound infection. Scand Cardiovasc J 2008; 42: 85-89.

13. Petzina R, Hoffmann J, Navasardyan A, Malmsjö M, Stamm C, Unbehaun A Hetzer R. Negative pressure wound therapy for post-sternotomy mediastinitis reduces mortality rate and sternal re-infection rate compared to conventional treatment. Eur J Cardiothorac Surg 2010; 38: 110-113.

14. Simek M, Hajek R, Fluger I, Molitor M, Grulichova J, Langova K, Tobbia P, Nemec $P$, Zalesak B, Lonsky V. Superiority of topical negative pressure over closed irrigation therapy of deep sternal wound infection in cardiac surgery. J Cardiovasc Surg (Torino) 2012; 53: 113-120. 